\title{
EXPERIMENTAL STUDY ON BIOMASS AIR-STEAM GASIFICATION EFFECTIVENESS IN DOWNDRAFT GASIFIER
}

\author{
Maksim Pavlenko ${ }^{1}$, Viacheslav Chuba ${ }^{1}$, Nataliya Tsyvenkova ${ }^{1,2}$, Marina Tereshchuk ${ }^{2}$ \\ ${ }^{1}$ National University of Life and Environmental Sciences of Ukraine, Ukraine; ${ }^{2}$ Zhytomyr National \\ Agroecological University, Ukraine \\ maxim_pavlenko@i.ua,vvchuba@ukr.net,nataliyatsyvenkova@gmail.com,marfa3127@yandex.ua
}

\begin{abstract}
Biomass gasification has been regarded as a promising technology to utilize bioenergy sustainably. However, further exploitation of biomass gasification still needs to overcome a significant number of technical and technological challenges. The results of an investigation of straw pellet air-steam gasification process effectiveness in downdraft gasifier are presented. The method is based on definition of $\mathrm{CoP}$ of a gasification process through composing material and heat balances. A design of a pilot gasifier plant with a downdraft gasifier is presented. An outcome of dry syngas from $1 \mathrm{~kg}$ of pellets with HHV $14.18 \mathrm{MJ} \cdot \mathrm{kg}^{-1}$ was $2.25 \mathrm{~m}^{3} \cdot \mathrm{kg}^{-1}$. The HHV of dry syngas was $11.836 \mathrm{MJ} \cdot \mathrm{kg}^{-1}$. The calculation errors of balances are: $1.82 \%$ for material and $0.83 \%$ for heat. It was found that use of an air-steam mixture as blast gases raises CoP of the gasification process to $83.4 \%$, which is more than classical methods of gasification. The analysis of balance made it possible to define harmful heat loses of the process. It was revealed that losses into environment $861 \mathrm{~kJ}^{-1} \mathrm{~kg}^{-1}(6.04 \%)$, losses with coke-like remainder $861 \mathrm{~kJ} \cdot \mathrm{kg}^{-1}(6.0 \%)$ and around $1 \%$ in total of losses are with moisture and tar. Directions of improvement of a downdraft gasifier are the design or operational mode optimization. The presented investigations could become a basis for a modern method of defining the effectiveness of the gasification process for stationary and mobile gasifiers as well. Using the obtained results the new laboratory practice for students of engineering courses was prepared and successfully tested.
\end{abstract}

Keywords: syngas, fuel, balances, heat value.

\section{Introduction}

Lectures on the disciplines "Designing and calculation of technological systems in horticulture", "Machines and equipment for biotechnologies" and "Methodology and technology of scientific investigations" include all fundamental engineering technologies, namely: bioenergetic systems [1], technological processes in bioenergetic complex [1;2], designing and producing machines and equipment for bioenergetics [3], exploitation of machines and equipment [3; 4], ensuring reliability and longevity of machines and equipment in bioenergetics [3; 4]. Master degree students study methods, technology and organization of scientific and investigation activities in the abovementioned direction, prepare reports about scientific work, reviews, scientific papers.

All lectures are completed by the themes carried out in practice, namely, biomass preparation [5; 6], biomass conversion into different kinds of fuels and energy generation from these fuels [7-10].

Curriculum of the disciplines "Designing and calculation of technological systems in horticulture" and "Machines and equipment for biotechnologies" includes studying of the process and equipment for thermo-chemical conversion of plant biomass into fuel, namely, "syngas". This gas can be used in internal combustion engines (ICE) for energy production, or associated to electric generators for electric energy production.

According to [11], gasification is a process that converts organic carbonaceous feedstock into $\mathrm{CO}$, $\mathrm{CO} 2, \mathrm{H} 2$ and $\mathrm{CH} 4$ by reacting the feedstock at high temperatures $\left(700-1500{ }^{\circ} \mathrm{C}\right)$, without combustion, with a controlled amount of oxygen and/or steam.

In different scientific literature [11-13] mode parameters and energetic performance of gasification of several types of biomass and solid fossil fuels are presented that deepen understanding of thermo-chemical conversions in gasifiers. At the same time, data from different authors differ by mode conditions, gas output, coke output, gas composition. This makes comparing different types of the conversion technology difficult. In some cases estimated data are given with significant value variation. In reality, this is due to the fact that a direct measurement of some parameters (hot gas dispent, tar content in gas, element composition of fuel and received products) is complicated and expensive.

Valuation of the solid fuel gasification process effectiveness is done via material and heat balances. These balances are composed based on the fuel and air quantity needed to receive $1 \mathrm{~m} 3$ of syngas, chemical composition of syngas and so on [14]. Studying heat processes of the gasification 
process makes it possible to estimate the main reasons of heat losses and to make up approaches to the problem of defyining the coefficient of performance of the gasification process.

The aim of this work is to define the effectiveness of the solid fuel gasification process (such as wheat straw, wood etc.) in a downdraft gasifier via composing material and heat balances and to get data for the laboratory study preparation for students of the engineering specialties.

When studying the disciplines "Designing and calculation of technological systems in horticulture" and "Machines and equipment for biotechnologies", students take part in designing the main assemblies of a gasifier. On practices they define the chemical composition of syngas, calculate the coefficient of performance $(\mathrm{CoP})$ of the gasification process, gasifier, gasifier plant, and compose material and heat balances of the process. Analyzing these balances, students with teachers are looking for ways to improve effectiveness of solid fuel gasification.

\section{Materials and methods}

Pellets (10 mm diameter and $50 \mathrm{~mm}$ length) produced from wheat straw were used as fuel for the gasifier. Quality factors of the pellets corresponded to DIN 51731 and ONorm M 7135. Chemical and technical parameters of the pellets produced from wheat straw affecting the working condition are as follows. Density: $1.14 \mathrm{~kg} \cdot \mathrm{dm}^{-3}$; moisture: $<10 \%$; ash: $<0.5 \%$; sulphur: $0.08 \%$; nitrogen: $0.3 \%$; chlorine: $0.03 \%$; dust: $2.3 \%$; HHV: $14.18 \mathrm{MJ} \cdot \mathrm{kg}^{-1}$. Standardized fuel was used to eliminate the effect of its humidity on the gasification process.

A technological process for syngas production and the block chart of a pilot gasifier plant with a downdraft gasifier have been developed for experimental studies and are given in Fig. 1. The gasifier output was $60-68 \mathrm{~m}^{3} \cdot \mathrm{h}^{-1}$. The plant included the following: a downdraft gasifier 1; a combined purifier 28 for syngas cooling and purification; a unit for gas sampling 16; a system for feed of blast gases included a double stage blower 2 for air supply to the gasifier and a flow controller.

The studies were carried out in the gasifier at an atmospheric pressure of $0.1 \mathrm{MPa}$. A gas electric generator was used to utilize the syngas. In order to receive syngas with $\mathrm{HHV} \geq 10 \mathrm{MJ} \cdot \mathrm{m}^{-3}$ at minimal fuel consumption for the gasification process, the air-gas recuperator 7 was designed (the basic model of the gasifier [15] did not include the air-gas recuperator 7 and the combined purifier 28). Recuperator utilizes about $90 \%$ of the syngas temperature and transfers it to the blown air. Air, preheated to a temperature of about $400-600^{\circ} \mathrm{C}$, moves along channels of the recuperator and reaches the evaporator chamber 20, where it is moistened with water steam. Gas pipe 8 is an integral part of the recuperator. The temperature of the syngas in the recuperator is reduced and condensation of the moisture contained therein takes place. To remove this moisture from the recuperator, the pipe 19 with a check valve is provided. Thanks to the check valve, the water steam does not enter the syngas. Extra moisture drains to the storage tank contained in the evaporator. Evaporator operation is synchronized with operation of the blast gas supply system. It makes possible to program the air humidity, which is supplied into the active zone of the gasifier.

Measurement and registration of the heating value of the syngas was carried out with the CM6G calorimeter 13 . The measurement results were automatically integrated by a PC. To determine the chemical composition of syngas in accordance with the requirements of DSTU ISO 6974-1:2007, the Agilent's $6890 \mathrm{~N}$ chromatograph was used. According to the chemical composition of the syngas thermal and material balances were compiled.

Duration of the laboratory study is $240 \mathrm{~min}$. The first $160 \mathrm{~min}$ are dedicated directly to experiment; the last $80 \mathrm{~min}$ are for composing the material and heat balances, determination of the gasification process and the gasifier effectiveness. Students are obligatory instructed about labour safety and all activities are held under supervision from the teacher.

At start, students load pellets to the gasifier bunker. Kindle the gasifier. Stable gasification process is observed after $20 \mathrm{~min}$ of operation. Air supply for gasification should be $40 \mathrm{~m}^{3} \cdot \mathrm{h}^{-1}$. Temperature in the active zone is measured with a type $\mathrm{C}$ thermocouple and should be $1100^{\circ} \mathrm{C}$.

Students determine the chemical composition of the syngas by using the Agilent $6890 \mathrm{~N}$ chromatograph. 


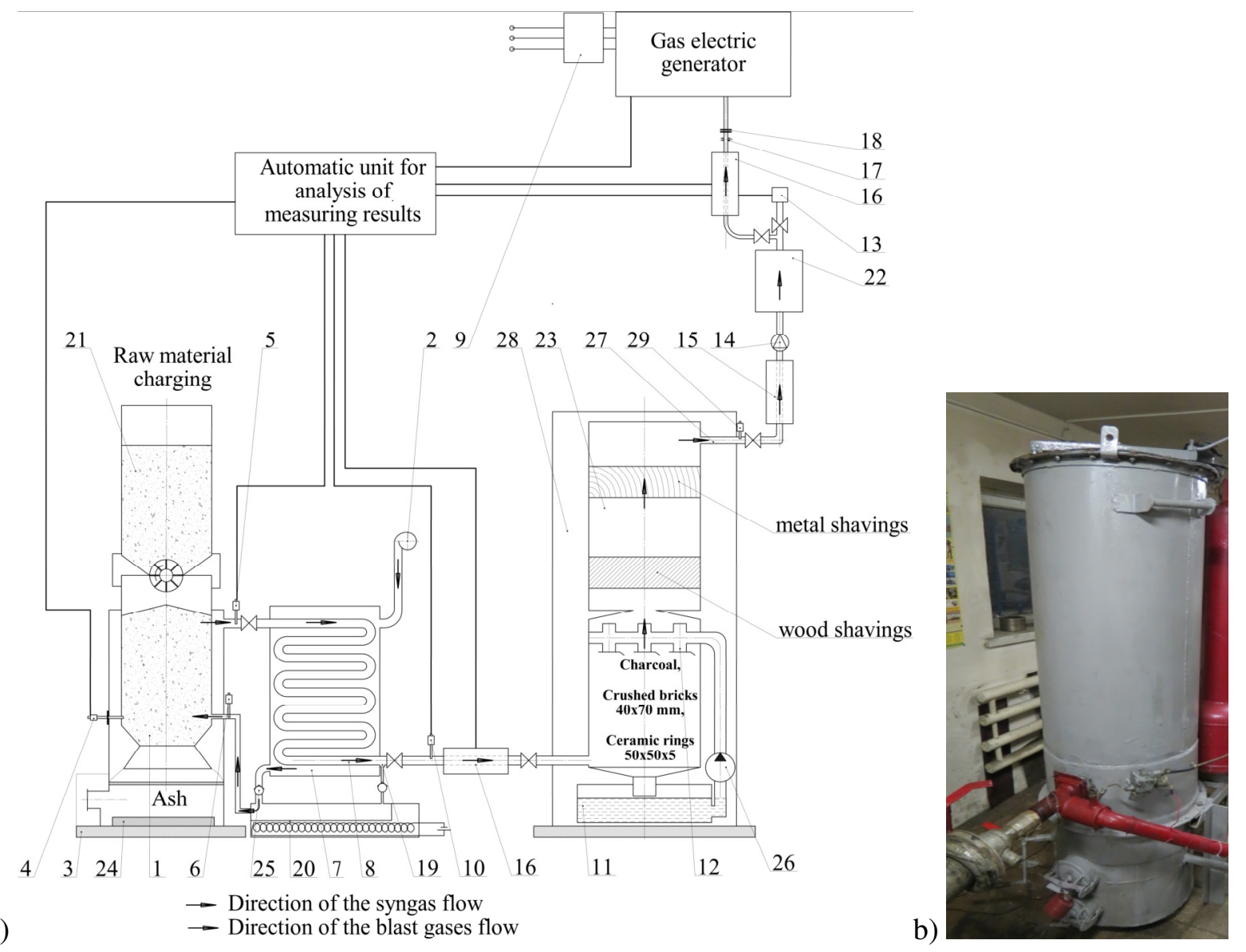

a)

Fig. 1. Pilot gasifier plant with a downdraft gasifier: $a$ - block chart; $b$ - general view;

1 - downdraft gasifier; 2 - double stage blower (GHBH 00434 2R5 3KW); 3 - laboratory scales TVE 500-10 according to DSTU EN 45501; 4 - type C thermocouple; 5, 6, 10 - type K thermocouple;

7 - air-gas recuperator; 8 - gas pipe; 9 - electricity meter; 11 - irrigated scrubber header;

12 - sprinkler; 13 - calorimeter CM6G; 14 - vacuum pump; 15, 16 - gas sampling unit; 17 - throttle washer for regulation of gas supply; 18 - choke; 19 - pipe with a check valve; 20 - evaporator chamber; 21 - raw bunker; 22 - receiver; 23 - dry stage of a combined purifier; 24 - scales TVE 1505 according to DSTU EN 45501; 25 - check valve; 26 - pump; 27 - gas feeding pipe;

28 - combined purifier; 29 - mercury thermometer TL-4 according to TC 25-2021.003-88

Initial data for material and heat balances are fuel elemental composition and chemical composition of the received gas. The method of calculation is developed by the authors of the paper.

Specific output of dry gas from $1 \mathrm{~kg}$ of fuel is defined by carbon balance [16; 17]. Elemental composition of $1 \mathrm{~kg}$ of working mass of fuel is expressed by equation:

$$
C^{w}+H^{w}+O^{w}+N^{w}+W^{w}+A^{w}=m_{\text {fuel }}^{w},
$$

where $C^{w}, H^{w}, O^{w}, N^{w}, W^{w}, A^{w}$ - carbon, hydrogen, oxygen, nitrogen, moisture, ash content in working mass of fuel, part by weight; $m_{\text {fuel }}^{w}$ - working mass of fuel equal to $1 \mathrm{~kg}$.

From $C^{w} \mathrm{~kg}$ of carbon contained in $1 \mathrm{~kg}$ of fuel only a part is transferred to gas:

$$
C_{\text {gas }}=C^{w}-C_{C}-C_{t a r} \text {, }
$$

where $C_{C}, C_{t a r}$ - mass of carbon in a coke like remainder of pellets that did not react, and in tar in terms of $1 \mathrm{~kg}$ of fuel.

$$
C_{C}=C^{C} \cdot m_{C} ; \quad C_{t a r}=q_{t a r} \cdot m_{t a r},
$$

where $C^{C}$ - carbon content in a coke like remainder of pellets, part by weight; 
$q_{\text {tar }}$ - carbon content in tar, part by weight;

$m_{c}, m_{\text {tar }}$ - mass of coke remainder and tar respectively, $\mathrm{kg}$.

$1 \mathrm{scm}$ (standard cubic meter) of dry syngas contains the following amount of carbon;

$$
C_{\text {gas }}=0.536 \cdot\left(\mathrm{CO}+\mathrm{CO}_{2}+\sum m \cdot \mathrm{C}_{m} \mathrm{H}_{n}\right),
$$

where 0.536 - ratio of carbon molecular weight to the volume of $1 \mathrm{~kg} \cdot \mathrm{mol}$ of gas at $0^{\circ} \mathrm{C}$ and $760 \mathrm{~mm} \mathrm{Hg}$;

$\mathrm{CO}, \mathrm{CO}_{2}, \mathrm{C}_{m} \mathrm{H}_{n}$ - content of carbonaceous gases in syngas, part by volume.

By dividing carbon quantity in fuel, which transferred to gas, by carbon content in $1 \mathrm{scm}$ of gas will receive the output of dry syngas from $1 \mathrm{~kg}$ of working mass of fuel [17]:

$$
V_{\text {gas }}=1.867 \cdot\left(C^{C}-C_{C}-C_{\text {tar }}\right)\left(\mathrm{CO}+\mathrm{CO}_{2}+\sum m \cdot C_{m} H_{n}\right)^{-1},
$$

where $\quad V_{\text {gas }}-$ dry gas output from $1 \mathrm{~kg}$ of working mass of fuel, $\mathrm{scm} \cdot \mathrm{kg}^{-1}$.

Density of dry gas at normal conditions is defined depending on its composition by formula [17]:

$$
\begin{aligned}
& \rho_{\text {gas }}=1.25 \cdot \mathrm{CO}+0.09 \cdot \mathrm{H}_{2}+0.72 \cdot \mathrm{CH}_{4}+1.26 \cdot \mathrm{C}_{2} \mathrm{H}_{4}+1.17 \cdot \mathrm{C}_{2} \mathrm{H}_{2}+1.34 \cdot \mathrm{C}_{2} \mathrm{H}_{6}+ \\
& +1.91 \cdot \mathrm{C}_{3} \mathrm{H}_{6}+2.02 \cdot \mathrm{C}_{3} \mathrm{H}_{8}+2.67 \cdot \mathrm{C}_{4} \mathrm{H}_{10}+1.98 \cdot \mathrm{CO}_{2}+1.25 \cdot \mathrm{N}_{2}
\end{aligned}
$$

where $\mathrm{CO}, \mathrm{H}_{2}, \mathrm{CH}_{4}, \mathrm{C}_{2} \mathrm{H}_{4}, \mathrm{C}_{2} \mathrm{H}_{2}, \mathrm{C}_{2} \mathrm{H}_{6}, \mathrm{C}_{3} \mathrm{H}_{6}, \mathrm{C}_{3} \mathrm{H}_{8}, \mathrm{C}_{4} \mathrm{H}_{10}, \mathrm{CO}_{2}, \mathrm{~N}_{2}$ - content of correspondent gases in dry syngas, part by volume; correspondent numeric coefficients define the density of gases at $0{ }^{\circ} \mathrm{C}$ i $760 \mathrm{~mm} \mathrm{Hg}$;

$\rho_{\text {gas }}$ - density of dry syngas at normal conditions, $\mathrm{kg} \cdot \mathrm{scm}^{-1}$.

Moisture content of a gas is defined from hydrogen balance. In the gasification process hydrogen is introduced with fuel. Hence, the quantity of steam in an output gas consists of hygroscopic moisture of fuel and pyrogenetic moisture, which is produced of fuel hydrogen, minus the hydrogen content in tar and gases. Moisture weight in $1 \mathrm{scm}$ of gas:

$$
d_{\text {gas }}=\left(W^{w}+9 H^{w}-9 h_{\text {tar }} m_{\text {tar }}-0.804\left[H_{2}+\sum 0.5 \cdot n \cdot C_{m} H_{n}\right]\right) V_{\text {gas }}^{-1},
$$

where $h_{\text {tar }}$ - hydrogen content in tar, part by weight;

0.804 - steam density at $0{ }^{\circ} \mathrm{C}$ and $760 \mathrm{~mm} \mathrm{Hg}, \mathrm{kg} \cdot \mathrm{scm}^{-1}$;

$d_{g a s}$ - moisture weight in $1 \mathrm{scm}$ of gas, $\mathrm{kg} \cdot \mathrm{scm}^{-1}$.

Total volume of humid gas, produced from $1 \mathrm{~kg}$ of working mass of fuel, consists of the dry gas volume and steam volume [17]:

$$
d_{\text {gas }}^{\text {wet }}=V_{\text {gas }}(1+1.245) \cdot d_{\text {gas }},
$$

where $d_{\text {gas }}^{\text {wet }}$ - humid gas volume, produced from $1 \mathrm{~kg}$ of working mass of fuel, $\mathrm{scm} \cdot \mathrm{kg}^{-1}$.

Air supply for gasification of $1 \mathrm{~kg}$ of fuel is defined from nitrogen material balance, which transfers from air to gas (nitrogen in fuel is neglected due to a very small amount).

Stating that the nitrogen content in air is 0.79 by volume and measured volumetric part of nitrogen in a syngas is $\mathrm{N}_{2}$, then to produce $1 \mathrm{scm}$ of gas $1.266 \cdot \mathrm{N}^{2}$ of air is needed. Hence, to gasify $1 \mathrm{~kg}$ of working mass of fuel should be supplied an amount of air:

$$
V_{\text {air }}=1.266 \cdot V_{\text {gas }} \cdot N_{2} \text {, }
$$

where $V_{\text {air }}$-air supply for gasification of $1 \mathrm{~kg}$ of working mass of fuel, $\mathrm{scm} \cdot \mathrm{kg}^{-1}$.

To check correctness and certainty of definition of the gasification process parameters material and heat balances are composed.

According to the matter conservation law, the weight of substances spent for gasification should be equal to the weight of substances received after the process. A material balance equation in terms of $1 \mathrm{~kg}$ of working mass of fuel:

$$
m_{\text {fuel }}^{w}+m_{\text {air }}+m_{\text {steam }}=m_{\text {gas }}+m_{C}+m_{\text {moisture }}+m_{\text {tar }},
$$


where $m_{f u e l}^{w}$ - working mass of fuel equal to $1 \mathrm{~kg}$.

$m_{\text {air }}$ - air spent for gasification of $1 \mathrm{~kg}$ of fuel; $m_{\text {air }}=V_{\text {air }} \cdot \rho_{\text {air }}, \mathrm{kg}$;

$m_{\text {gas }}-$ dry gas weight from $1 \mathrm{~kg}$ of fuel; $m_{\text {gas }}=V_{\text {gas }} \cdot \rho_{\text {gas }}, \mathrm{kg}$;

$m_{c}$ - coke remainder weight; $m_{c}=0.02 \cdot m_{\text {fuel }}, \mathrm{kg}$;

$m_{\text {tar }}, m_{\text {moisture }}, m_{\text {steam }}-$ tar, moisture and steam weight respectively, $\mathrm{kg}$.

The method of calculation of the heat balance is as follows.

The heat balance could be composed as with a higher heat value $(H H V)$, so with a lower heat value $(L H V)$ of the produced gas and gasified fuel. In our case we use $H H V$.

$$
Q_{1}+Q_{2}+Q_{3}+Q_{4}=Q_{5}+Q_{6}+Q_{7}+Q_{8}+Q_{9}+Q_{10},
$$

$Q_{1}, Q_{2}, Q_{3}$ and $Q_{4}$, compose the income part and $Q_{5}, Q_{6}, Q_{7}, Q_{8}, Q_{9}, Q_{10}$, make the outcome part. Calculation of each is shown below.

Potential heat of gasified fuel $Q_{1}, \mathrm{~J}$ :

$$
Q_{1}=Q_{H H V} \cdot m_{\text {fuel }}^{w},
$$

where $Q_{H H V}-\mathrm{HHV}$ of gasified fuel, $\mathrm{J} \cdot \mathrm{kg}^{-1}$.

Physical heat of fuel, J:

$$
Q_{2}=m_{\text {fuel }}^{w} \cdot C_{\text {fuel }} \cdot t_{\text {fuel }},
$$

where $t_{\text {fuel }}-$ temperature of fuel loaded to the gasifier, ${ }^{\circ} \mathrm{C}$;

$C_{\text {fuel }}$ - mean fuel heat capacity within temperature range 0 to $\mathrm{t}_{\text {fuel }}, \mathrm{J} \cdot\left(\mathrm{kg} \cdot{ }^{\circ} \mathrm{C}\right)^{-1}$.

Heat of dry air fed to the gasifier $Q_{3}, \mathrm{~J}$ :

$$
Q_{3}=m_{\text {air }} \cdot C_{\text {air }} \cdot t_{\text {mix }},
$$

where $t_{m i x}$ - steam-air mixture temperature near the gasifier entrance, ${ }^{\circ} \mathrm{C}$;

$C_{a i r}$ - mean air heat capacity within temperature range 0 to $t_{m i x}, \mathrm{~J} \cdot\left(\mathrm{kg} \cdot{ }^{\circ} \mathrm{C}\right)^{-1}$.

Heat of steam $Q_{4}$ in a steam-air mixture, J:

$$
Q_{4}=\left(m_{\text {steam }}+d_{\text {air }} \cdot m_{\text {air }}\right) \cdot X \cdot i_{\text {steam }},
$$

where $d_{\text {air }}$-air humidity, $\mathrm{kg} \cdot \mathrm{kg}^{-1}$;

$X$ - coefficient of dryness of saturated steam, \%;

$i_{\text {steam }}$ - heat capacity of saturated steam at $t_{m i x}, \mathrm{~J} \cdot(\mathrm{kg})^{-1}$.

The outcome part consists of HHV of the dry syngas, heat of the water steam in the syngas, physical heat of the syngas, heat value of coke-like remainder of biomass, HHV of tar. The rest are: unaccounted heat losses, heat loss to environment and observation errors.

The higher heat value of the syngas $Q_{5}, \mathrm{~J}$ :

$$
Q_{5}=Q_{H H V}^{\text {gas }} \cdot m_{\text {gas }},
$$

where $Q_{H H V}^{g a s}-$ the higher heat value of syngas, $\mathrm{J} \cdot(\mathrm{kg})^{-1}$.

Physical heat of gas $Q_{6}, \mathrm{~J}$ :

$$
Q_{6}=m_{\text {gas }} \cdot C_{\text {gas }} \cdot t_{\text {gas }},
$$

where $t_{\text {gas }}$ - syngas temperature, ${ }^{\circ} \mathrm{C}$;

$C_{\text {gas }}$ - mean heat capacity of dry syngas between 0 to $t_{\text {gas }}{ }^{\circ} \mathrm{C}, \mathrm{J} \cdot\left(\mathrm{kg} \cdot{ }^{\circ} \mathrm{C}\right)^{-1}$. $\mathrm{J} \cdot(\mathrm{kg})^{-1}$

Heat capacity of a syngas $C_{g a s}$ is calculated via the heat capacities of its every component, 


$$
\begin{aligned}
& C_{\text {gas }}=C_{\mathrm{CO}_{2}} \cdot \frac{\mathrm{CO}_{2}^{g}}{100}+C_{\mathrm{O}_{2}} \cdot \frac{\mathrm{O}_{2}^{g}}{100}+C_{\mathrm{C}_{2} \mathrm{H}_{4}} \cdot \frac{C_{2} H_{4}^{g}}{100}+ \\
& +C_{\mathrm{CH}_{4}} \cdot \frac{\mathrm{CH}_{4}^{g}}{100}+C_{\mathrm{CO}} \cdot \frac{\mathrm{CO}^{g}}{100}+C_{\mathrm{H}_{2}} \cdot \frac{\mathrm{H}_{2}^{g}}{100}+C_{\mathrm{N}_{2}} \cdot \frac{N_{2}^{g}}{100}
\end{aligned}
$$

where $\mathrm{CO}_{2}{ }^{g}, \mathrm{O}_{2}{ }^{g}, \mathrm{C}_{2} \mathrm{H}_{4}{ }^{g}, \mathrm{CH}_{4}{ }^{g}, \mathrm{CO}^{g}, \mathrm{H}_{2}{ }^{g}, \mathrm{~N}_{2}{ }^{g}$ - weight percentages of the corresponding gases per kilogram of syngas.

Heat capacities of methan and ethylene are taken from [13].

Heat of steam in syngas $Q_{7}, \mathrm{~J}$ :

$$
Q_{7}=d_{\text {gas }} \cdot m_{\text {gas }} \cdot i_{h . s t e a m},
$$

where $\quad d_{\text {gas }}-$ moisture content in syngas, $\mathrm{kg} \cdot(\mathrm{kg})^{-1}$;

$i_{\text {h.steam }}$ - heat capacity of an overheated water steam, $\mathrm{J} \cdot(\mathrm{kg})^{-1}$. It is calculated with:

$$
i_{\text {h.steam }}=i_{\text {d.p. }}+C_{\text {steam }} \cdot\left(t_{\text {gas }}-t_{\text {d.p. }}\right),
$$

where $i_{d . p .}$ - heat content of a kilogram of saturated steam at the dew point corresponding to syngas saturation, $\mathrm{J} \cdot(\mathrm{kg})^{-1}$ of water steam;

$C_{\text {steam }}$ - mean heat capacity of steam between $t_{\text {d.p. }}$ to $t_{\text {gas }}, \mathrm{J} \cdot\left(\mathrm{kg} \cdot{ }^{\circ} \mathrm{C}\right)$;

$t_{d . p .}$ - dew point temperature determined by elasticity of the water steam according to the psychrometer readings, ${ }^{\circ} \mathrm{C}$.

High heat value of tar contained in gas $Q_{8}, \mathrm{~J}$ :

$$
Q_{8}=Q_{H H V}^{t a r} \cdot m_{t a r},
$$

where $Q_{H H V}^{t a r}-$ higher heat value of tar in syngas, $\mathrm{J} \cdot(\mathrm{kg})^{-1}$.

The higher heat value of coke-like remainder $Q_{9}, \mathrm{~J}$ :

$$
Q_{9}=Q_{H H V} \cdot m_{c},
$$

The last component $Q_{10}$ that contains all loses and unaccounted heat is defined as the difference between income and already estimated outcome:

$$
Q_{10}=\sum Q_{1-4}-\sum Q_{5-9},
$$

Coefficient of performance of the gasification process:

$$
\eta=Q_{H H V}^{\text {gas }} \cdot H \cdot C_{\text {gas }}^{C} \cdot C_{\text {fuel }}^{-1},
$$

where $H$ - ratio between the quantity of dry gas, received from burning gasified fuel in stechiometric quantity of air, and dry combustion products;

$C^{C}$ gas - percentage of carbon transferred into gas, $\%$.

$$
\mathrm{H}=\mathrm{CO}_{2 \text { max }} \cdot\left[\mathrm{CO}_{2}+\mathrm{O}_{2}+\mathrm{CH}_{4}+\mathrm{CO}+\mathrm{H}_{2}+\mathrm{C}_{2} \mathrm{H}_{4}\right]^{-1},
$$

where $\mathrm{CO}_{2 \max }$ - maximal content of $\mathrm{CO}_{2}$ in dry combustion products received from burning gasified fuel in theoretic quantity of air, \%;

$\mathrm{CO}_{2}, \mathrm{O}_{2}, \mathrm{C}_{2} \mathrm{H}_{4}, \mathrm{CH}_{4}, \mathrm{CO}, \mathrm{H}_{2}$ - content of respective components in syngas, \%.

$\mathrm{CoP}$ of the gasification process could also be calculated in a simpler way:

$$
\eta=Q_{H H V}^{g a s} \cdot 100 \cdot Q_{H H V}^{-1},
$$

The proposed procedure provides an opportunity of general energy assessment for the process of air-steam gasification of straw pellets in a downdraft gasifier and determination of the effectiveness of this process. 


\section{Results and discussion}

The chemical composition of syngas defined based on 7 samples made with 5 minute intervals was: $\mathrm{CO}-28.64 \% ; \mathrm{H}_{2}-28.52 \% ; \mathrm{CO}_{2}-7.77 \% ; \mathrm{N}_{2}-32.06 \% ; \mathrm{CH}_{4}-2.81 \% ; \mathrm{C}_{2} \mathrm{H}_{4}-0.2 \%$. An outcome of dry gas from $1 \mathrm{~kg}$ of pellets was $2.25 \mathrm{~m}^{3} \cdot \mathrm{kg}^{-1}$. Tar content in syngas was accepted according to [10], which is $0.1-1.2 \mathrm{~g} \cdot \mathrm{scm}^{-1}$.

Gasifier heat balance includes all heat supplied to and taken from the gasifier. The heat brought to the gasifier consists of the fuel heat value, its physical heat and the enthalpy of the air and steam introduced into the hearth and reduction zones of the gasifier.

Consumption items include the higher heat value of dry syngas and its physical heat, physical heat of steam in syngas, as well as the heat value of tar, coke-like remainder of wheat pellets and a residual component. This component contains all unaccounted heat losses, heat losses to environment and observational errors. The values of the material and heat balances are given in Table 1 and Table 2. Analyzing the values of the heat balance, we can see a general picture of energy flows in the gasifier.

Table 1

\section{Material balance of the gasifying process}

\begin{tabular}{|l|c|c|c|}
\hline \multicolumn{2}{|c|}{ Material input } & \multicolumn{2}{c|}{ Material consumption } \\
\hline 1. & Mass of working fuel $-1.000 \mathrm{~kg}$ & 1. & Mass of dry gas $-1.754 \mathrm{~kg}$ \\
\hline 2. & Mass of air $-0.980 \mathrm{~kg}$ & 2. & Mass of condensate $-0.359 \mathrm{~kg}$ \\
\hline 3. & Mass of water steam $-0.245 \mathrm{~kg}$ & 3. & Mass of tar $-0.0015 \mathrm{~kg}$ \\
\hline \multicolumn{2}{|c|}{ Total $-2.225 \mathrm{~kg}$} & 4. & Mass of coke-like remainder $-0.07 \mathrm{~kg}$ \\
\hline- & \multicolumn{2}{c|}{ Total $-2.185 \mathrm{~kg}$} \\
\hline \multicolumn{2}{|c|}{ The calculation error of material balance is $1.82 \%$} \\
\hline
\end{tabular}

Table 2

Heat balance of the gasifying process

\begin{tabular}{|c|c|c|c|}
\hline \multicolumn{2}{|c|}{ Heat input } & $\mathbf{k J} \cdot \mathbf{k g}^{-1}$ & $\mathbf{\%}$ \\
\hline 1. & Potential heat of the fuel $Q_{1}$ & 14181.0 & 98.73 \\
\hline 2. & Physical heat of the fuel $Q_{2}$ & 52.0 & 0.36 \\
\hline 3. & Heat of dry air fed to the gasifier $Q_{3}$ & 102.0 & 0.71 \\
\hline 4. & Heat content of blast water steam $Q_{4}$ & 29.0 & 0.20 \\
\hline \multicolumn{2}{|c|}{ Total } & 14364.0 & 100.00 \\
\hline 1. & Heat consumption & $\mathrm{kJ} \cdot \mathrm{kg}^{-1}$ & $\%$ \\
\hline 2. & Higher heat value of syngas $Q_{5}$ & 11836.0 & 83.08 \\
\hline 3. & Physical heat of gas $Q_{6}$ & 583.0 & 4.09 \\
\hline 4. & Heat of steam in syngas $Q_{7}$ & 28.0 & 0.59 \\
\hline 5. & Calorific value of tar $Q_{8}$ & 0.20 \\
\hline 6. & Heat value of coke-like remainder $Q_{9}$ & 854.0 & 6.00 \\
\hline \multicolumn{2}{|c|}{ Residual component } & 861.0 & 6.04 \\
\hline
\end{tabular}

The presented material and heat balances (Table 1 and Table 2), composed based on experimentally defined composition of gas, prove the effectiveness of use of steam-air blast for gasification of straw containing fuels and certainty of the presented method. The calculation error of material balance was $1.82 \%$. The calculation error of heat balance was $0.83 \%$.

Also, the analyzis of heat balance components (Table 2) helps define harmful heat loses and their reasons and to find methods of their elimination. Coefficient of performance of the gasification process was $83.4 \%$. A high value of losses into environment $861 \mathrm{~kJ} \cdot \mathrm{kg}^{-1}(6.04 \%)$, losses with cokelike remainder $861 \mathrm{~kJ} \cdot \mathrm{kg}^{-1}(6.0 \%)$ and around $1 \%$ in total of losses with moisture and tar are seen.

After analyzing the reasons of mentioned losess, $\mathrm{CoP}$ of the gasification process could be raised up to $90 \%$. Directions could be the design improvement or operational mode optimization of a downdraft gasifier. 
The aim of the study was not only experimental study on biomass air-steam gasification effectiveness in a downdraft gasifier, but also to find, if it is possible to make a laboratory study that students can perform in $240 \mathrm{~min}$. It is found that our results correlate with the data from predecessors [18-21]. Later it was proved that performing this laboratory study is possible in the laboratory of the Department of Tractors, Vehicles and Bioenergy Systems of the National University of Life and Environmental Sciences of Ukraine (NULES), and also at the Department of Mechanics and Engineering of Agroecosystems of the Zhytomyr National Agroecological University (ZNAEU). Therefore, the practice with the title "An experimental study on biomass air-steam gasification effectiveness in a downdraft gasifier" was prepared and tested at teaching.

\section{Conclusions}

The aim was to verify the published investigations in literature sourses and to get data for the laboratory study preparation for the students of the engineering faculties of ZNAEU and NULES of Ukraine. The experimental studies of biomass air-steam gasification effectiveness in a downdraft gasifier have led to the following conclusions.

1. A method of calculation of material and heat balances of air-steam gasification of low grade fuels in a downdraft gasifier is presented. The calculation error of material balance was $1.82 \%$. The calculation error of heat balance was $0.83 \%$. It was found that use of a steam-air mixture as blast gases raises $\mathrm{CoP}$ of the gasification process to $83.4 \%$, which is more than classical methods of gasification.

2. It should be admitted that the results received by students in laboratory studies correlate with the results published by other authors. Using the obtained results, the new laboratory study was prepared and successfully tested for the students of the subjects "Designing and calculation of technological systems in horticulture", "Machines and equipment for biotechnologies" and "Methodology and technology of scientific investigations".

\section{References}

[1] Golub G., Kukharets S., Yarosh Y. etc. Integrated use of bioenergy conversion technologies in agroecosystems. INMATEH - Agricultural Engineering, vol. 51, No. 1, 2017, pp. 93-100.

[2] Ryabchenko O., Golub G., Turčeková N. etc. Sustainable business modeling of circular agriculture production: Case study of circular bioeconomy. Journal of Security and Sustainability, vol. 7, No. 2, 2017, pp. 301-309. DOI: 10.9770/jssi.2017.7.2(10).

[3] Відновлювана енергетика в аграрному виробництві: навч. посіб./За ред. Скидана О. В., Голуба Г. А. (Renewable energy in agricultural production : tutorial/edited by Skydan O., Golub G.). Kyiv: NULES of Ukraine, 2018, 338 p. (In Ukrainian).

[4] Holubenko A., Tsyvenkova N., Nezdvetskaya I., Pluzhnikov O. The results of investigation of corrosion processes in gasifyer when gasifying fuels containing straw and lignin. Proceedings of International conference "Engineering for rural development 2019", May 22-24, 2019, Jelgava, Latvia, pp. 1415-1422.

[5] Голуб Г., Кухарець С., Чуба В., Марус О. Виробництво і використання біопалив в агроекосистемах. Механіко-технологічні основи: монографія (Biofuels production and use in agroecosystems. Mechanical and technological fundamentals: monograph). Kyiv: NULES of Ukraine, 2018, 254 p. (In Ukrainian).

[6] Golub G., Marus O., Chuba V., Pavlenko M. Research of the hydro-mechanical mixer parameters for diesel biofuel production with using box-benghken experiment plan. Agricultural Engineering International: CIGR Journal, vol. 21, No. 4, 2019, pp. 121-131.

[7] Kukharets S., Tsyvenkova N., Yarosh Ya. etc. The results of study into the effect of air-steam blast on the low-grade fuel gasification process. Eastern-European Journal of Enterprise Technologies, vol. 6, No. 8(96), 2018, pp. 86-96.

[8] Голуб Г., Чуба В. Експлуатаційні параметри роботи двигуна при застосуванні дизельного біопалива (Engine performance when using diesel biofuels). Науковий вісник НУБіП України. Серія «Техніка та енергетика АПК», vol. 196, No. 1, 2014, pp. 23-31. 
[9] Golub G., Kukharets S., Tsyvenkova N., etc. Research on a boiler furnace module effectiveness working on small fracture wastes. INMATEH - Agricultural Engineering, vol. 55, No. 2, 2018, pp. 9-18.

[10] Golub G., Kukharets S., Tsyvenkova N. etc. Experimental study into the influence of straw content in fuel on parameters of generator gas. Eastern-European Journal of Enterprise Technologies, vol. 5, No. 8, 2018, pp. 76-86. DOI: 10.15587/1729-4061.2018.142159

[11] Basu P. Biomass gasification, pyrolysis and torrefaction: practical design and theory. Elsevier, 2013. 548 p. Available at: DOI: $10.1016 / \mathrm{c} 2011-0-07564-6$

[12] Barmina I., Valdmanis R., Zake M., etc. Development of gasification/combustion characteristics at thermo-chemical conversion of biomass mixtures. Proceedings of International conference "Engineering for rural development 2017", May 24-26, 2017, Jelgava, Latvia, pp. 54-59.

[13] Malmgren A., Riley G. Biomass power generation. Comprehensive Renewable Energy, vol. 5, 2012, pp. 27-53.

[14] Klius S., Zhovmir M, Maslyukova Z., Demchyna V. Evaluation of main parameters and efficiency of partial biomass. Renewable energy, vol. 2, 2016, pp. 79-87.

[15] Tsyvenkova N., Golubenko A., Kukharets S., Biletsky V. The research of downdraft gas producer heat productivity on straw. Annals of the Faculty of Engineering Hunedoara, vol. 15, iss. 3, 2017, pp. 213-218.

[16]Reed T., Das A. Handbook of Biomass Downdraft Gasifier Engine Systems. Golden: Solar Energy Research Institute, 1988. 140 p. DOI: 10.2172/5206099

[17]Мезин И.С. Транспортные газогенераторы (Automotive gas producers). Moskow: Ogiz Selhozgiz, 1948, 311 p. (In Russian).

[18] Susastriawan A.A.P., Saptoad H., Purnomo. Small-scale downdraft gasifiers for biomass gasification: A review. Renewable and Sustainable Energy Reviews, vol. 76, 2017, pp. 989-1003.

[19] Corella J., Toledo J. M., Molina Gr. Steam gasification of coal at low-medium $\left(600-800^{\circ} \mathrm{C}\right)$ temperature with simultaneous $\mathrm{CO} 2$ capture in a bubbling fluidized bed at atmospheric pressure. 2. Results and recommendations for scaling up. Industrial \& Engineering Chemistry Research, vol. 47, Issue 6, 2008, pp. 1798-1811. doi: 10.1021/ie0714192

[20] Sepe A. M., Li J., Paul M. C. Assessing biomass steam gasification technologies using a multipurpose model. Energy Conversion and Management, vol. 129, 2016, pp. 216-226. DOI: 10.1016/j.enconman.2016.10.018

[21] Franco C., Pinto F., Gulyurtlu I., Cabrita I. The study of reactions influencing the biomass steam gasification process. Fuel, vol. 82, issue 7, 2003, pp. 835-842. DOI: 10.1016/S00162361(02)00313-7 